\title{
НЕОБХІДНІСТЬ РОЗВИТКУ ВОЛОНТЕРСЬКОГО РУХУ СЕРЕД СТУДЕНТІВ-МЕДИКІВ
}

\author{
О. В. Руденко \\ Комунальний заклад “Бердянський медичний коледж» Запорізької обласної ради \\ У статті йдеться про роботу волонтерської бригади Бердянського медичного коледжу та про \\ необхідність розвитку волонтерського руху серед студентів-медиків.

\section{NECESSITY OF DEVELOPMENT OF VOLUNTEER MOVEMENT AMONG MEDICAL STUDENTS}

\author{
O. V. Rudenko \\ Munisipal Establishment «Berdyansk Medical College» \\ of Zaporizhzhya Regional Council
}

The given article deals with the work of volunteer team under the drigade of Berdyansk Medical College and covers the necessity of development of volunteer movement among medical students.

Вступ. Нинішні соціально-економічні умови роблять дітей та підлітків прагматичними. Далеко не кожна молода людина здатна стати волонтером. Волонтерство має бутидобровільним вибором, який би відображав особисті погляди й позиції людини. Головними принципами волонтерської діяльності повинні бути: добровільність, рівність, моральність, добросовісність, самовдосконалення, законність, безвідплатність. В Україні поняття «волонтерські організації, «волонтерство», "волонтерський рух» для позначення важливого значення соціально-політичного життя суспільства дедалі стрімко набуває масового поширення. У нашій країні волонтерський рух, детермінований гуманізацією суспільного життя, $є$ відповіддю на суспільні потреби.

Основна частина. Волонтерський рух існує вже багато сторіч. I хоча в різних країнах це явище має різні назви, воно є універсальним людським феноменом, який зустрічається в усіх культурах, на всіх рівнях економічного розвитку, серед представників обох статей і людей різного віку. Він $\epsilon$

$\overline{\text { (C) О. В. Руденко, } 2014}$ однією з найефективніших форм роботи $з$ молоддю, невичерпним джерелом набуття громадянської освіти, дає можливість реалізувати себе у служінні суспільству.

Відповідно до Закону України «Про волонтерську діяльність», прийнятого Верховною Радою 19 квітня 2011 року, «волонтерська діяльність добровільна, безкорислива, соціально спрямована, неприбуткова діяльність, що здійснюється волонтерами та волонтерськими організаціями шляхом надання волонтерської допомоги. Волонтерська допомога - роботи та послуги, що безоплатно виконуються та надаються волонтерами та волонтерськими організаціями. Волонтерська діяльність $\epsilon$ формою благодійництва» [2].

Волонтерська діяльність здійснюється за такими напрямами:

- надання волонтерської допомоги з метою підтримки малозабезпечених, безробітних, багатодітних, безпритульних осіб, які потребують соціальної реабілітації;

- здійснення догляду за хворими, інвалідами, одинокими, людьми похилого віку та іншими осо- 
бами, які через свої фрізичні, матеріальні чи інші особливості потребують підтримки та допомоги;

- надання допомоги громадянам, які постраждали внаслідок стихійного лиха, екологічних, техногенних та інших катастроф, у результаті соціальних конфліктів, нещасних випадків, а також жертвам злочинів, біженцям;

- надання допомоги особам, які через свої фізичні або інші вади обмежені в реалізації своїх прав і законних інтересів;

- проведення заходів, пов'язаних з охороною навколишнього природного середовища, збереженням культурної спадщини, історико-культурного середовища, пам'яток історії та культури, місць поховання;

- сприяння проведенню заходів національного та міжнародного значення, пов'язаних із організацією масових спортивних, культурних та інших видовищних і громадських заходів;

- надання волонтерської допомоги для ліквідації наслідків надзвичайних ситуацій техногенного або природного характеру;

- надання волонтерської допомоги за іншими напрямами, не забороненими законодавством [2].

Велика кількість громадських організацій поєднує молодих людей, які на добровільних засадах беруть участь у соціальних програмах. Однією з таких програмє створення волонтерської мультидисциплінарної бригади в Бердянському медичному коледжі, яка працюе вже понад п'ять років. Викладачами циклу професійної та практичної підготовки було створено волонтерську мультидистанційну бригаду «Милосердя». До складу цієї бригади входять викладачі клінічних дисциплін лікарі, студенти випускних курсів спеціальності «Сестринська справа», «Лікувальна справа» та психолог коледжу. Усі члени бригади «Милосердя» пройшли спеціальну підготовку: прослухали курс лекцій стосовно психологічної підтримки людей похилого віку, особливості догляду за пацієнтами похилого віку з різними захворюваннями.

Члени волонтерської бригади «Милосердя» співпрацюють із міським Товариством Червоного Хреста та допомагають мешканцям геронтологічного пансіонату. Вони вважають, що проблема старіння людини завжди була актуальною, старіння населення (тобто збільшення частки осіб пенсійного віку в загальній чисельності населення) нині набуває великого значення, дуже багато людей доживають до похилого віку й залишають- ся самотніми [6]. Такі люди потребують паліативної допомоги, яку в першу чергу можуть надати медичні працівники, а саме студенти-медики.

На даний момент в Україні вже здійснені певні кроки в напрямку розвитку цієї сфери, зокрема, створено Інститут паліативної допомоги, поступово розробляється необхідна нормативна база, та водночас, існує чимало проблем. Аналітичного підґрунтя досі не вистачає, не проведена оцінка того, який підхід до надання паліативної допомоги $\epsilon$ найефективнішим для України й наскільки готове суспільство до активного впровадження паліативних програм [4].

У той же час старіння нації, прогрес невиліковних хвороб і зменшення частки працездатного населення приводить до того, що власне медичний, соціальний догляд і психологічний супровід хворих, які перебувають на межі смерті, стають все більш і більш необхідними. Тому посильна допомога волонтерів завжди стає в пригоді.

Паліативна допомога студентів-медиків - це комплексний підхід, мета якого забезпечити максимально можливу якість життя паліативних хворих, шляхом запобігання та полегшення страждань завдяки ранньому виявленню й точному діагностуванню симптомів болю та розладів життєдіяльності, проведення адекватних лікувальних заходів, симптоматичної терапії та догляду, надання психологічної, соціальної, духовної та моральної підтримки, незалежно від захворювання, віку, соціального статусу, національності, релігійних та політичних переконань, місця проживання хворого тощо [9].

Паліативна допомога не $\epsilon$ альтернативою інтенсивного лікування, спочатку вона виступає як долікарський вид допомоги, роль якої все більше зростає у міру прогресування захворювання або старіння людини, що викликає обмеження можливостей та інше сприйняття світу людиною. Тому саме в цей час людині необхідна моральна і психологічна підтримка.

Під час відвідування геронтологічного пансіонату члени волонтерської бригади під керівництвом викладача-лікаря виконують медичні маніпуляції (вимірюють артеріальний тиск, накладають компреси, роблять ін'єкції, змінюють постільну танатільну білизну, годують та доглядають тяжкохворих, студенти, які пройшли курси масажу та мають посвідчення, роблять масаж), здійснюють необхідні покупки, допомагають у прибиранні 
кімнат, а найголовніше - дарують їм увагу, тепло та душевне спілкування.

Волонтери бригади «Милосердя» влаштовують мешканцям геронтологічного пансіонату вечори відпочинку до таких свят, як: 9 травня, Новийрік та Різдво, 8 березня, оскільки саме уваги та душевного тепла не вистачає самотнім дідусям та бабусям. Вони живуть у постійному очікуванні нової зустрічі, чергової теплоїрозмови. Для багатьох із них - це сенс життя, усвідомлення того, що вони все ж таки комусь потрібні.

\section{ЛІТЕРАТУРА}

1. Паліативна медицина: організаційні і педагогічні аспекти / Г. Боднар, І. Вітенко, А. Попович [та ін.] // Медична освіта. - 2003. - № 2. - С. 7-9.

2. Закон України «Про волонтерську діяльність».

3. Касимовская Н. А. Паллиативная помощь - медицинская услуга? / Н. А. Касимовская / / Медсестра. 2009. - № 10. - С. 4.

4. Про організацію паліативної допомоги в Україні : наказ № 41 від 21.01.2013 р. МОЗУ.

5. Решения VIКонгресса с международным участием «Паллиативная медицина иреабилитация в здравоохранении» / / Паллиативная медицина иреабилитация. -2004 . - № 2-3. - C. 6-12.
Висновок. Волонтерський мультидисциплінарний підхід до комплексного забезпечення потреб пацієнтів при наданні паліативної допомоги має велике значення. Волонтерська діяльність студентів-медиків як прояв милосердя й доброзичливості буде існувати доти, доки існує потреба людей у тій чи іншій допомозі та обмежена державна участь у задоволенні потреб своїх громадян, їхній соціальній підтримці.

6. Тарасюк В. С. Медсестринство в геронтології геріатріі : підручник / В. С. Тарасюк, Г. Б. Кубанська. -К. : ВСВ «Медицина», 2010. - 648 с.

7. ТуркинаН.В. Обучение социальных работников / Н. В. Туркина, И. П. Королева, Н. А. Кощеева / / Медицинская сестра. - 2010. - № 1. - С. 13-14.

8. Хосписнаяипаллиативнаяпомощь: от теориикпрактике / О.И. Усенко, Л. М. Рябова, С. С. Святова [та ін. ]. / / Медицинская сестра. - 2010. - № 6. - С. 3-10.

9. Шатило В. Й. Паліативна медицина : підручник / В.Й.Шатило, П. В. Яворський. - К. : ВСВ «Медицина», 2010. -200 c.

Отримано 24.04.14 